AGROLAND: The Agricultural Sciences Journal

Vol. 8, No. 2 December (2021), 144 - 151

P-ISSN : 2407- 7585 \& E-ISSN : 2407- 7593, Published by Tadulako University

Original Research

Open Access

\title{
HYDROPONIC VEGETABLE MARKETING STRATEGY IN PALU CITY INDONESIA
}

\author{
Shintami R. Malik ${ }^{1)}$, Sulmi $^{1)}$, Husnul Khatima ${ }^{1)}$, Lien Damayanti ${ }^{1)}$, Rustam Abd.Rauf ${ }^{1)}$ \\ ${ }^{1)}$ Lecturer of Agribusiness Study Program, Faculty of Agriculture, Tadulako University \\ Correspondence author's: Shintami R. Malik \\ Email: shintami978@gmail.com
}

Submit: 1 Desember 2021, Revised: 8 Desember 2021, Accepted: December 2021

DOI : https://doi.org/10.22487/agroland.v8i2.1150

\begin{abstract}
Hydroponics is plant cultivation that utilizes water media without using soil. The hydroponic vegetable products produced are diverse, ranging from kale, bok choy, mustard greens, and lettuce. This study aimed to identify internal and external factors that influence marketing and identify marketing strategies for hydroponic vegetables in Palu City. The results showed that the evaluation of the internal and external factors showed that the strength factor had a score of 1.85 , the weakness factor was 1.26 , the opportunity factor was 1.74 , and the threat factor was 1.16. Thus, the highest score was achieved by internal factors (strength) of 1.85 , and the lowest was the weakness of 1.16. Hydroponic vegetable marketing in Palu City is in the SO Strategy. In this condition, it has great power and great opportunities to market.
\end{abstract}

Keywords: Marketing, Hydroponic Vegetables, SWOT

\section{INTRODUCTION}

Hydroponics is the growing of plants in which water is used as the planting medium instead of soil to provide the nutritional needs of the plants (Khan, Purohit, and Vadsaria 2021; Maucieri et al. 2019). Aside from hydroponics, there is an appropriate method for growing plants to fulfill the community's supplies of vitamins and minerals while taking advantage of a little yard. Mustard greens, spinach, lettuce, and kale are some of the plants that are commonly produced in a hydroponic system (Aires 2018; Basri and Maheasy 2020).
The Palu City government supports the rapid development of hydroponic plants, as evidenced by the Department of Agriculture and Food Security of Palu City, which displays samples of hydroponic plant installations in front of the office to observe and produce similar things. Furthermore, this hydroponic technology is appropriate for the landscape with limited lands, such as Palu City. Agriculture using a hydroponic system does not necessitate a considerable amount of land. However, it is only worth considering in the hydroponic farming business since it can be done in the yard, on the roof of the home, or on another land (Roidah, 2014). 
Many consumers are interested in buying hydroponic vegetables since they are starting to care about their health. Hydroponic vegetable items produced include water spinach, bok choy, mustard greens, and lettuce. According to research conducted by Santi et al. (2019), local people are very concerned about their health. They may prevent and avoid memorable diseases caused by toxic chemicals by eating hydroponic veggies (Cifuentes-Torres et al., 2021; Steven 2019). Hydroponic vegetables are superior to regular vegetables in terms of quality, as hydroponic plants contain higher quantities of vitamins and minerals and are therefore more helpful to human health (BBPP-Lembaga, 2017).

The cost of hydroponic veggies is higher than that of traditional vegetables. Lettuce, for example, costs between Rp.40,000 and Rp.50,000 per kilogram, whereas bok choy costs between Rp.20,000 and Rp.25,000 per kilogram. This is due to the high prices and investments required to develop hydroponic vegetables. This is in line with the findings of Sengkey et al. (2017), who claim that many people still produce crops in soil medium because farming with hydroponics is very expensive and takes training to get adequate expertise to be effective in employing hydroponic techniques (Khan, Purohit, and Vadsaria 2021; Suryani et al. 2020). Logically, higher quality and consistent vegetable products are sold at a higher price, allowing increased production expenses to be paid by a higher selling price. However, it is worth noting that the ability of consumers to pay more for higher-quality items and services that come with them has a significant impact on the relationship between quality and price. The more the willingness of consumers to pay a higher price for superior quality vegetables, the more options there are to offer them at higher rates (Noviani, 2016).

Because each farm is located in a residential neighborhood and can be accessible by the owners, hydroponic vegetable gardens and marketing in Palu
City is highly advantageous. According to Santi et al. (2019), the location of hydroponic vegetable gardens and marketing in Pontianak City is strategic since every hydroponic farm is placed in complexes with numerous settlements, and hydroponic marketing locations are in markets where many people care about health (Aires 2018; Sambo et al. 2019)

Hydroponic producers' promotions have been widely publicized both direct and indirectly. By incorporating hydroponic gardening, producers can achieve their full potential. Social media platforms such as Whatsapp, Instagram, and Facebook are already being used by online marketing. The use of social media (WhatsApp, Instagram, and Facebook) in the marketing of hydroponic vegetables will make it easier for producers to run promotions, as the expenses are low and the information load is high (Santi et al., 2019). However, the campaigns carried out by the two promotional media were not as effective as they could have been.

Researchers want to learn more about the marketing strategy for hydroponic vegetables in Palu City to reformulate a better and more sustainable marketing plan for hydroponic crops in the future. The following is the formulation of the problem in this study, based on the background:

a. What internal (strengths and weaknesses) and external (opportunities and threats) elements influence hydroponic vegetable marketing in Palu City?

b. What is Palu City's hydroponic vegetable marketing strategy?

This study aims to determine internal (strengths and weaknesses) and external (opportunities and threats) elements that influence hydroponic vegetable marketing in Palu City. In addition, the study also considered understanding Palu City's hydroponic vegetable marketing plan.

\section{RESEARCH METHODS}

\section{Location and Time of Research}

The research was conducted in Palu City. The location selection was 
determined purposively, considering that the development of hydroponic vegetables in Palu City was relatively rapid. This research was carried out from February to August 2021.

\section{Sampling and Sampling Techniques}

Determination of key informants (Key Samples in this study was conducted by purposive method) with 12 respondents consisting of 5 producers (farmers/ hydroponic vegetable producers, production division, marketing division), five consumers, and two respondents from Palu city government.

\section{Data source}

Sources of data used are primary data in the form of observations and interviews with respondents with the help of a list of questions (Questionnaire) following the research objectives and secondary data in the form of data collected, processed, and presented by other parties in the form of books and results of previous research.

\section{Analysis Method}

\section{SWOT analysis}

The purpose of this research will be answered using a SWOT analysis (strengths, weaknesses, opportunities, threats) where a SWOT analysis is used to produce the right marketing strategy to be applied to the Hydroponic Vegetable business in Palu City. The SWOT analysis is a useful analysis to obtain the proper strategy formulation. This analysis is a systematic identification of various factors to formulate a strategy on a logical basis that can maximize strengths and opportunities but simultaneously minimize weaknesses and threats (Rangkuti, 2009).

\section{Internal Factors (IFAS) and External Factors (EFAS)}

The internal strategic factors are then compiled in an IFAS (Internal Factor Analysis Summary) table to formulate the internal factors of Kibo Tawaeli's Hydroponics business. The external strategic factors are compiled in an EFAS (External Strategic Factor Analysis Summary) table.

The analysis stage of IFAS and EFAS is by giving the rating and weight values contained in the IFAS and EFAS tables. They were calculating the rating for each factor by giving a scale ranging from 4 (outstanding) to 1 (poor), based on the influence of these factors on the company's internal and external conditions. Weighting each of these factors on a scale ranging from 1.0 (most important) to 0.0 (not important), based on these factors, to the company's strategic position (all these weights must not exceed a total score of 1.0) (Rangkuti, 2009).

\section{OPORTUNITIES}

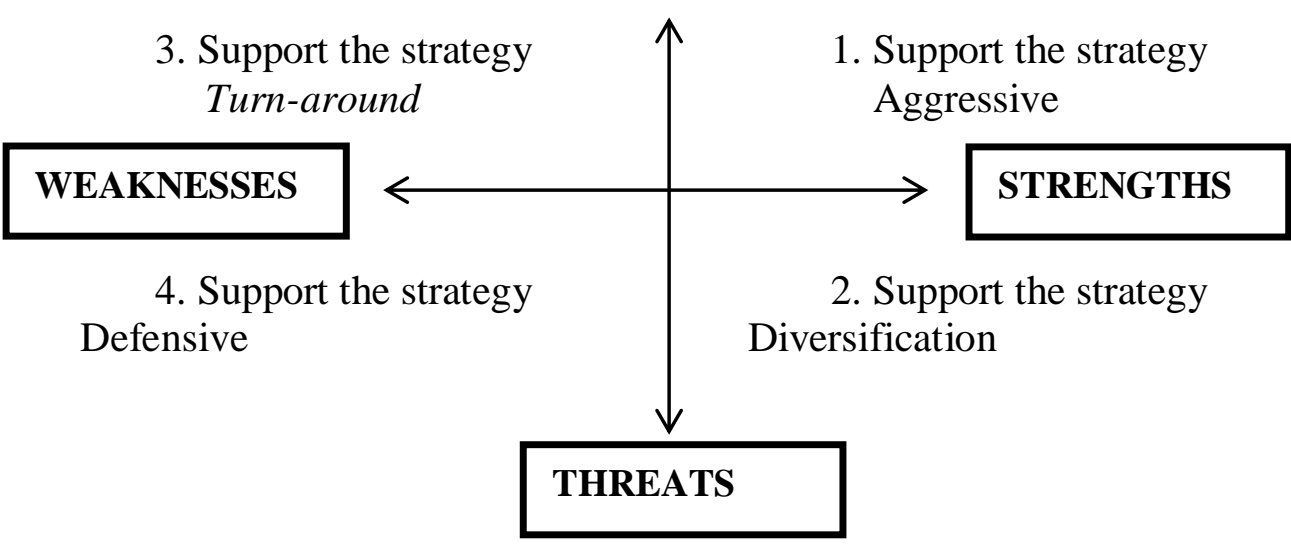

Figure 1. SWOT Diagram 
Table 1. SWOT Matrix Diagram and Possible Appropriate Strategies

\begin{tabular}{cll}
\hline \multicolumn{1}{c}{ IFAS/EFAS } & \multicolumn{1}{c}{ Strenghts $(\boldsymbol{S})$} & \multicolumn{1}{c}{ Weaknesses $(\boldsymbol{W})$} \\
\hline Opportunities $(\boldsymbol{O})$ & $\begin{array}{l}\text { SO Strategy } \\
\text { Creating strategies that use } \\
\text { strengths to take advantage of } \\
\text { opportunities. }\end{array}$ & $\begin{array}{l}\text { WO Strategy } \\
\text { Creating strategies that minimize } \\
\text { weaknesses to take advantage of } \\
\text { opportunities. }\end{array}$ \\
\hline Threats $(\boldsymbol{T})$ & $\begin{array}{l}\text { ST Strategy } \\
\text { Creating strategies that use } \\
\text { strength to overcome } \\
\text { threat. }\end{array}$ & $\begin{array}{l}\text { WT Strategy } \\
\text { Creating strategies that use } \\
\text { strength to overcome } \\
\text { threat. }\end{array}$ \\
\hline
\end{tabular}

Source: Rangkuti, 2009

Table 2. IFAS Matrix of Hydroponic Vegetable Marketing in Palu City, 2021.

\begin{tabular}{|c|c|c|c|c|c|}
\hline \multirow[b]{2}{*}{ No } & INTERNAL FACTORS & \multicolumn{3}{|c|}{ MEANS } & \multirow[b]{2}{*}{ SCORE } \\
\hline & STRENGHTS & $\begin{array}{l}\text { IMPORTANT } \\
\text { VALUE }\end{array}$ & WEIGHT & RATE & \\
\hline 1 & Strategic Location & 4.0 & 0.09 & 3.67 & 0.34 \\
\hline 2 & Affordable prices & 4.3 & 0.10 & 3.58 & 0.36 \\
\hline 3 & Pesticide free product & 5.0 & 0.12 & 4.00 & 0.47 \\
\hline 4 & High demand & 4.4 & 0.10 & 3.67 & 0.38 \\
\hline \multirow[t]{2}{*}{5} & Easy processing and maintenance & 4.0 & 0.09 & 3.25 & 0.30 \\
\hline & $\begin{array}{ll}\text { WEAKNESSES } & \text { Total }\end{array}$ & 21.75 & 0.51 & 18.17 & 1.85 \\
\hline 1 & $\begin{array}{l}\text { Variations of Hydroponic Vegetable } \\
\text { Products }\end{array}$ & 4.25 & 0.10 & 2.50 & 0.25 \\
\hline 2 & Limited Product Quantity & 4.08 & 0.10 & 2.67 & 0.25 \\
\hline 3 & $\begin{array}{l}\text { The packaging does not have a } \\
\text { label/ brand }\end{array}$ & 4.17 & 0.10 & 2.33 & 0.23 \\
\hline 4 & $\begin{array}{l}\text { Promotion through offline is not } \\
\text { optimal yet }\end{array}$ & 4.42 & 0.10 & 2.67 & 0.27 \\
\hline \multirow[t]{3}{*}{5} & $\begin{array}{l}\text { Training on hydroponic vegetables } \\
\text { is still lacking }\end{array}$ & 4.17 & 0.10 & 2.67 & 0.26 \\
\hline & Total & 21.08 & 0.49 & 12.83 & 1.26 \\
\hline & Grand Total & 42.83 & 1.00 & 31.00 & 3.12 \\
\hline
\end{tabular}

SWOT analysis can be used to determine income-generating strategies by analyzing a combination of the intersection of the abscissa line (strengths-weaknesses) and the ordinate line (opportunitiesthreats) on the SWOT analysis diagram. Values on the $\mathrm{x}$ and $\mathrm{y}$ axes on the SWOT diagram are taken from the weight of $X$ rating on internal factors and $\mathrm{Y}$ weight on external factors.

Description:

Quadrant I: This is a very profitable situation because the company has opportunities and strengths to take advantage of current opportunities. The strategy that must be applied in this condition is to support an aggressive growth policy (growth-oriented strategy).

Quadrant II: Despite facing various threats, the company still has internal strength. The strategy that must be applied is to use strength to take advantage of long-term opportunities through a diversification strategy (product/market).

Quadrant III: In this condition, the company faces a huge market opportunity, 
but on the other hand, it faces several internal constraints/weaknesses to seize or maximize better opportunities, which is called a turn-around strategy.

Quadrant IV: This is unfavorable because it faces various internal threats and weaknesses thus a defensive or defensive strategy is needed.

\section{RESULTS AND DISCUSSION}

The results of the rating calculation on internal factors that affect the marketing of hydroponic vegetables in Palu City are presented in Table 2.

Table 3 shows that the total score of 2.91 is greater than the average value (2.5), which shows that the marketing of hydroponic vegetables in Palu City has a threat but can be overcome with its opportunities.

Based on the evaluation of internal and external factors, it can be seen that the strength factor has a score of 1.85 , the weakness factor is 1.26 , the opportunity factor is 1.74 , and the threat factor is 1.16 . Thus, the highest score was achieved by internal factors (strength) of 1.85, and the lowest was the weakness of 1.16

\section{IFAS and EFAS Matrix}

Based on the IFAS and EFAS analysis results that have been started, the IFAS and EFAS matrices and the SWOT analysis diagram can be described in Table 3 and Figure 2.

Table 3. IFAS and EFAS Matrix of Hydroponic Vegetable Marketing in Palu City, 2021.

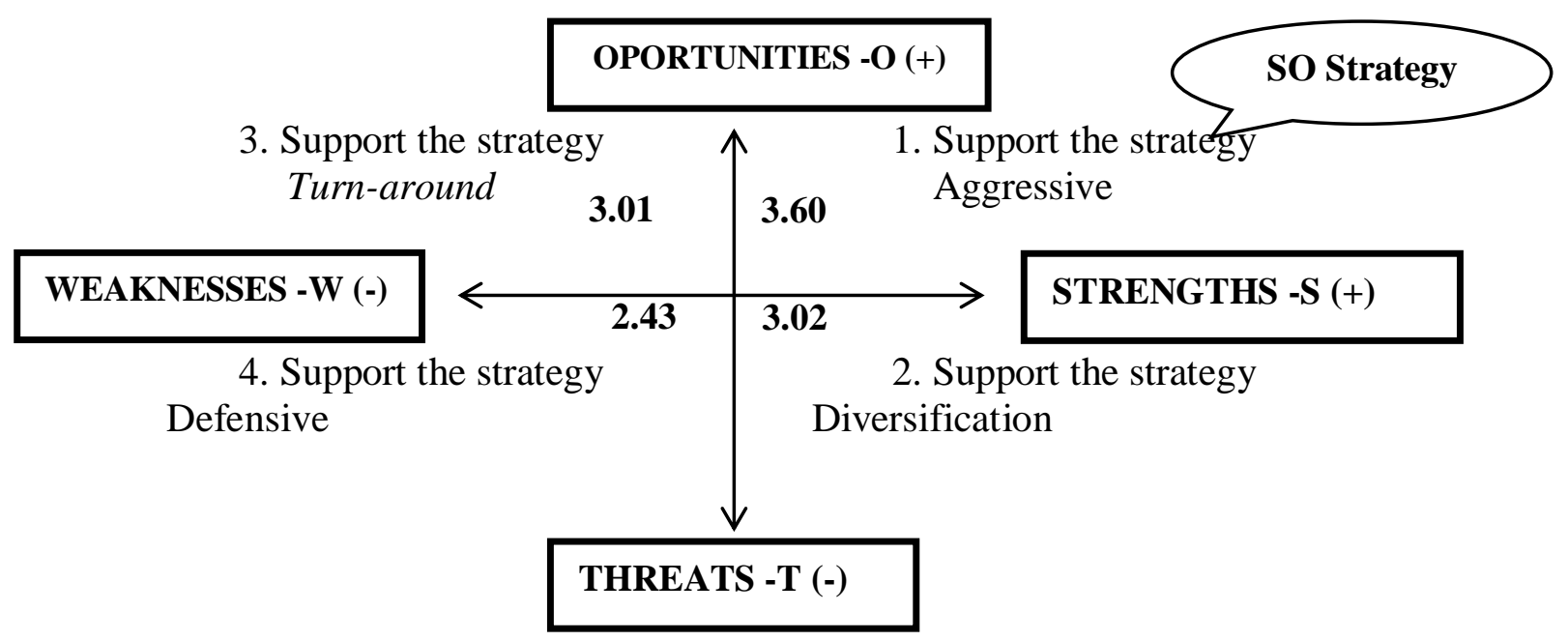

Figure 2. SWOT Analysis Diagram of Hydroponic Vegetable Marketing Strategy in Palu City, 2021

Observing the SWOT analysis diagram in Figure 2, the Hydroponic Vegetable Marketing Strategy can be formulated as follows:

Quadrant I:

It is a favorable situation because it has good opportunities and strengths because it is in a strategic location so that it is easy to market hydroponic vegetables, affordable prices, vegetables produced are free of harmful chemicals (pesticides), high consumer demand, easy management, and maintenance of vegetables.

Quadrant II:

Despite facing various threats, it still has internal strength in this condition. The strategy taken is to take advantage of a strategic location to increase income supported by increasing consumer demand and easy management and maintenance. The threats faced are competing with local vegetables, pests and plant diseases, 
differences in the price of hydroponic vegetables from outside the Palu city, water quality, and unpredictable weather can be minimized so that the marketing of hydroponic vegetable increases.

Quadrant III:

There is ample opportunity, namely public awareness to consume and high demand for hydroponic vegetables, but on the other hand, producers face several internal constraints/weaknesses. The strategy that must be done is to increase the variety of hydroponic vegetable products, make attractive packaging for consumers, promote both online and offline, and conduct training on hydroponic vegetable marketing so as to improve the quality and quantity of hydroponic vegetable marketing.

Quadrant IV:

This situation is very unfavorable for producers because the marketing of hydroponic vegetables faces various internal threats and weaknesses. The effort or strategy that must be applied in this condition is to maintain hydroponic vegetable production with limited resources.

\section{CONCLUSION}

Based on the study, the conclusion of hydroponic vegetables' marketing strategy in Palu City is the SO Strategy. In this condition, the marketing of hydroponic vegetables has strength because it has great opportunities to be marketed.

\section{REFERENCES}

Aires, Alfredo. 2018. "Hydroponic Production Systems: Impact on Nutritional Status and Bioactive Compounds of Fresh Vegetables." In Vegetables - Importance of Quality Vegetables to Human Health, edited by Md. Asaduzzaman and Toshiki Asao. InTech. https://doi.org/10.5772/intechopen. 73011.
Asriani., Wa Embe., Fitria Napu., Dhian Herdhiansyah., 2020. Persepsi Masyarakat terhadap Agribisnis Sayuran Metode Hidroponik Starterkit Wick di Kota Kendari. Mimbar Agribisnis. Jurnal Pemikiran Masyarakat Ilmiah Berwawasan Agribisnis. Januari 2020 6(1) : 11-18

Assauri, Sofjan, 2002. Manajemen Pemasaran Dasar Konsep dan Strategi, PT Raja Grafindo Persada, Jakarta.

Basri, Arie Hapsani Hasan, and Mahmudah Mahmudah. 2020. "THE EFFECT OF HYDROPONIC NUTRITION LEVELS ON THE GROWTH OF MUSTARD (BRASSICA SP.) PLANTS." SINTA Journal (Science, Technology, and Agricultural) 1 (1): 40-52. https://doi.org/ 10.37638/sinta.1.1.40-52.

Cifuentes-Torres, Liliana, Leopoldo G. Mendoza-Espinosa, Gabriel Correa-Reyes, and Luis Walter Daesslé. 2021. "Hydroponics with Wastewater: A Review of Trends and Opportunities." Water and Environment Journal 35 (1): 16680. https://doi.org/10.1111/wej.12617.

BBPP-Lembaga. (2017). Balai Besar Pelatihan Pertanian Lembaga. Kementerian Pertanian Badan Penyuluh Dan Pengembangan SDM Pertanian.

Eka Handriani, 2011.Pengaruh Faktor Internal Eksternal, Entrepreneurial Skill, Strategi Dan Kinerja Terhadap Daya Saing Ukm Di Kabupaten Semarang, Dinamika Sosial Ekonomi, Volume 7 Nomor 1, Edisi Mei 2011, Hal. 47-48.

Fahmi, Irham., 2010. Manajemen Risiko Teori, Kasus, Dan Solusi, Alvabeta Bandung. 
Khotijah, Siti., 2004. Smart Strategi Of Marketing Persaingan Pasar Global, AFABETA, Bandung,

Kotler Philip. 2002. Manajemen Pemasaran, terjemahan Hendra Teguh, edisi Millinium, cetakan kesepuluh, Prenhalindo, Jakarta.

2009 Menejemen

Pemasaran, Erlangga, Jakarta.

Khan, Saad, Ankit Purohit, and Nikita Vadsaria. 2021. "Hydroponics: Current and Future State of the Art in Farming." Journal of Plant Nutrition 44 (10): 15-38. https://doi.org/10.1080/01904167.2 020.1860217.

Maucieri, Carmelo, Carlo Nicoletto, Erik van Os, Dieter Anseeuw, Robin Van Havermaet, and Ranka Junge. 2019. "Hydroponic Technologies." In Aquaponics Food Production Systems, edited by Simon Goddek, Alyssa Joyce, Benz Kotzen, and Gavin M. Burnell, 77-110. Cham: Springer International Publishing. https://doi.org/10.1007/978-3-03015943-6_4.

Suryani, Ela, Lisa Virdinarti Putra, Na'imah Much Muf'afidah, and Cholifatul v Lestari, Endah Prapti. 2011. Pemasaran Strategik: Bagaimana Meraih Keunggulan Kompetitif Edisi Pertama. Graha Ilmu. Yogyakarta.

Nilasari, Senja. 2014. Manajemen Strategi. Dunia Cerdas. Jakarta Timur.

Noviani, Nomi dan Sri Wahyuni., 2016. Analisis Strategi Pemasaran Sayuran Hidroponik Merek Papamama Farm. Jurnal Penelitian Pendidikan Sosial Humaniora, Vol 1 No 1 Mei th 2016, pp 29-42.

Rangkuti., 2009. Ananlisis SWOT. Gramedia Pustaka Utama. Jakarta
Roidah, Ida Syamsu., 2014. Pemanfaatan Lahan dengan Menggunakan Sistem Hidroponik. Jurnal Universitas Tulungagung Bonorowo Vol 1. No 2 Tahun 2014.

Rosliani, R., dan Sumarni, N. 2005. Budidaya Tanaman Sayuran dengan Sistem Hidroponik. Monografi (27) : ISBN : 979-840336-2. Balai Penelitian Tanaman Sayuran. Bandung.

Sambo, Paolo, Carlo Nicoletto, Andrea Giro, Youry Pii, Fabio Valentinuzzi, Tanja Mimmo, Paolo Lugli, et al. 2019. "Hydroponic Solutions for Soilless Production Systems: Issues and Opportunities in a Smart Agriculture Perspective." Frontiers in Plant Science 10 (July): 923.https://doi.org/10.3389/ fpls.2019.00923.

Sami, Abdulkadir., Mohammad Harisudin, Setyowati., 2017. Strategi Pemasaran Sayuran Hidroponik di PT. Kebun Sayur Segar Parung Farn Kabupaten Bogor Provinsi Jawa Barat. Agrista : Vol 5 No 3 September 2017 : 1-13 ISSN : 2301-1713.

Santi, Eva Dolorosa., dan Imelda. 2019. Strategi Pemasaran Sayuran Hidroponik Lokal di Kota Pontianak. Jurnal Sains Mahasiswa Pertanian Vol 8, No 2 (2019)., April 2019.

Sedarmayanti. 2014. Manajemen Strategi, Edisi 1. PT Refika Aditama. Bandung

Sengkey, Mercy Y., Welson M. Wangke., dan Elsje P. Manginsela., 2017. Persepsi Masyarakat terhadap Hidroponik di Kelurahan Teling Bawah, Kota Manado. Agri-Sosio Ekonomi Unstrat, ISSN 19074298, Volume 13 Nomor 2, Mei 2017 :33-46. 
Steven, George. 2019. "Chemical Contents of Hydroponic Plants." International Journal of Chemical \& Material Sciences. https://doi.org/10.31295/ijcms.v2n 1.83 .

Hidayah. 2020. "Analysis of the Hydroponics Program in Instilling an Environmental Care Attitude for Elementary School Students." Jurnal Penelitian Dan Pengkajian
Ilmu Pendidikan: E-Saintika 4 (3): 299. https://doi.org/10.36312/esaintika.v4i3.273

Sutiyoso, Y. 2004. Hidroponik ala Yos. Penebar Swadaya. Jakarta.

Wijaya, Indra dan Sri Setyo Iriani. 2013. Pengaruh Citra Merek Terhadap Loyalitas Konsumen.Jurnal Ilmu Manajemen, Vol. 1 No.3 Mei 2013, hlm 911. 